\title{
My first meeting with Rosalie David
}

\author{
Kay Hinckley
}

When I think of the wonderful character and ability of Rosalie David, I cannot help but feel that it was no accident that our lives crossed. People are often sent at the right time in one's life to give a clear direction and help enhance the future.

Rosalie and I first met when I was a passenger on a Nile boat where she was a lecturer. I was amazed at the number of lectures she gave and, indeed, by the wonderful support given to Rosalie by her late husband Antony. Through a mutual friend we soon became very close. I was so interested in her lectures that I took notes and, having read them, Rosalie suggested that I join her Certificate of Egyptology course at the University of Manchester. It was wonderful to have a year of excellent teaching, which I thoroughly enjoyed. The present certificate course is delivered by Joyce Tyldesley, another clever Egyptologist and an example of Rosalie's fine judgement of people.

The KNH Centre for Biomedical Egyptology was born at a table in Christie's Bistro, Manchester University, where Rosalie told me the history of Egyptology at Manchester, and gave me her vision for the future. Afterwards I felt that here was another Jesse Haworth and Flinders Petrie partnership. I was attracted by the possibility of enabling young and clever people to achieve their interests and fulfil their talents. It was very pleasing to be able to endow a chair in a field that Manchester did not previously have: a chair in Egyptology had been an unfulfilled dream of Margaret Murray, and a reminder of the fact that many of Flinders Petrie's archaeological finds were donated to the museum by Jesse Howarth in the hope that they would form the basis of a teaching department.

We had an official opening of the KNH Centre by HRH Prince Edward, followed by an official dinner for the great and good of the university. Since then, my interest and financial support have been rewarded one thousand fold. The centre has gone from strength to strength and each member of the 
team has been totally admirable. We have even had a lovely romance among the centre staff? Rosalie and I wish her successor at the KNH Centre, Andrew Chamberlain, every success.

In the Valley of the Kings some years ago, Rosalie and I had just visited three tombs when a prominent Egyptian walked up to us and said, 'Ah Rosalie David; when you are in Egypt, she sings.' After thanking him sincerely, Rosalie turned to me and said, 'Come on Kay, we are going to a fourth tomb.' I think no finer tribute can be paid to a most remarkable career. 
Campbell Price, Roger Forshaw, Andrew Chamberlain, Paul T. Nicholson, and Robert Morkot - 9781784997502 Downloaded from manchesterhive.com at 04/26/2023 12:50:06PM 